\title{
ANALISIS PERAN AFFILIATED COMMISSIONER DALAM PENERAPAN GOOD CORPORATE GOVERNANCE PADA BISNIS KELUARGA
}

\author{
Meco Sitardja ${ }^{1}$,Iwan Lesmana ${ }^{2}$,Safrida Rumondang ${ }^{3}$,Dheny Biantara ${ }^{4}$, Sri Handayani ${ }^{5}$ \\ 1,2,3,4,5 Universitas Agung Podomoro, Jakarta \\ meco.sitardja@podomorouniversity.ac.id
}

\begin{abstract}
This study aims to analyze the role of the board of commissioners in the implementation of Good Corporate Governance in family businesses. This study analyzed 18 research samples using purposive sampling method. In addition, this study uses an empirical normative approach. The results of the study indicate that the implementation of Good Corporate Governance in affiliated commissioner is quite good in the aspect of Responsiveness and Fairness. In further research, measurements of Good Corporate Governance can be added to several measurements of the ASEAN Governance Scorecard which include details of aspects that need to be carried out in supervision such as financial control, operational performance, risk management, internal control and performance appraisal of directors.
\end{abstract}

Keywords: Good Corporate Governance, affiliated commissioner, family business

\begin{abstract}
Abstrak
Penelitian ini bertujuan untuk menganalisis peran dewan komisaris pada penerapan Good Corporate Governance pada bisnis keluarga. Penelitian ini menganalisis 18 sampel penelitian dengan menggunakan metode purposive sampling. Selain itu, penelitian ini menggunakan pendekatan normatif empiris. Hasil penelitian menunjukkan bahwa penerapan Good Corporate Governance dalam affiliated commissioner cukup baik dalam aspek Pertanggung jawaban dan Kewajaran. Dalam penelitian selanjutnya, pengukuran Good Corporate Governance dapat ditambahkan beberapa pengukuran ASEAN Governance Scorecard yang mencakup rincian aspek-aspek yang perlu dilakukan dalam pengawasan seperti kontrol keuangan, kinerja operasional, manajemen risiko, pengendalian internal dan penilaian kinerja direksi.
\end{abstract}

Kata kunci : Good Corporate Governance, affiliated commissioner, bisnis keluarga

\section{Pendahuluan}

Bisnis keluarga adalah bentuk lama dari bisnis dan mayoritas perusahaan dunia merupakan bisnis keluarga (Frasl \& Rieger, 2007; Heck \& Trent, 1999). Bentuk bisnis ini merupakan fenomena global karena memberikan kontribusi yang signifikan terhadap ekonomi suatu Negara. Perusahaan keluarga beroperasional di banyak industri dan datang dari berbagai ukuran dan bentuk hukum, yang dimulai dari mikro, kecil, medium sampai dengan perusahaan besar baik publik mapun privat. Perusahaan keluarga menjadi sumber utama penyediaan pekerjaan dan pendapatan untuk lebih dari 5\% dari GDP nasional (Ferramosca \& Ghio, 2017).
Di dalam Eropa, ada sekitar 70-80\% perusahaan yang dimiliki oleh keluarga. Peringkat pertama dikuasai oleh perusahaan asal Italia sekitar 99\% (LeMar, 2001). Selain itu, perusahaan di Negara Amerika Serikat juga dimiliki oleh keluarga sebanyak 95\% (Schwass, et. al, 2004). Menurut data PwC tahun 2014, bisnis di Indonesia dimiliki keluarga sebesar 95\% (Wijaya \& Wijaya, 2017). Mulai dari bisnis keluarga dalam skala kecil, menengah, maupun dalam skala besar. Berdasarkan pada Indonesia Brand Forum (2016), total kekayaan bisnis keluarga di Indonesia mencapai US $\$ 134$ miliar atau sekitar $25 \%$ dari PDB (Produk Domestik Bruto) Indonesia. Dan sekitar 40.000 orang terkaya di Indonesia adalah pemilik perusahaan keluarga. 
Jurnal Ekonomi : Journal of Economic

p-ISSN 2087-8133| e-ISSN : 2528-326X

Keterlibatan anggota keluarga dalam manajemen perusahaan dapat menimbulkan benturan kepentingan di masa depan. Benturan kepentingan adalah keadaan di mana terdapat konflik antara kepentingan ekonomis Perusahaan dan kepentingan ekonomis pribadi pemegang saham, anggota Dewan Komisaris dan Direksi, serta karyawan Perusahaan (KNKG, 2006). Menurut UU No 8 tahun 1995 tentang Pasar Modal Pasal 1 angka 1, hubungan afiliasi adalah hubungan keluarga karena perkawinan dan keturunan sampai derajat kedua, baik secara horizontal maupun vertikal. Bahkan untuk posisi Komisaris Independen, anggota Dewan Komisaris tidak terafiliasi dengan Direksi, anggota Dewan Komisaris lainnya serta pemegang saham kendali sehingga tidak dapat mempengaruhi kemampuannya untuk bertindak independen. Ini seiring dengan teori keagenan yang menyatakan adanya konflik kepentingan antara manajer (owned-manager) dan pemegang saham (shareholder) yang digambarkan sebagai hubungan agensi (agency relationship) dimana dalam hal ini adalah Pemilik Perusahaan, Dewan Komisaris dan Dewan Direksi (Jensen \& Meckling, 1976).

Bank Dunia, sebagaimana yang dikutip oleh Transparency International tahun 2002 melaporkan bahwa krisis ekonomi di Asia Timur disebabkan oleh kegagalan sistemik dalam penerapan Corporate Governance (CG), yaitu kerangka hukum yang lemah, ketidak konsistenan dalam standard akuntansi dan pemeriksaan, praktik perbankan yang buruk, ketidak efektifan supervisi oleh Dewan Komisaris, dan ketidak cukupan perlindungan hak pemegang saham minoritas. Lebih lanjut, hasil penelitian yang dilakukan Asian Development Bank (ADB) tahun 1999 menunjukkan bahwa kegagalan penerapan CG merupakan penyebab krisis yang terjadi di beberapa Negara Asia (Indonesia, Malaysia, Filipina, Thailand dan Korea). Ditemukan bahwa kegagalan tersebut dihasilkan dari adanya:1) struktur kepemilikan yang terkonsentrasi $\quad(57 \%$ sampai $65 \%), 2)$ mekanisme pengawasan oleh Dewan Komisaris yang tidak berfungsi secara efektif, 3) tidak adanya kontrol pasar terhadap perusahaan, dominasi pendanaan eksternal yang berasal dari pinjaman bank, dan 4) ketidak cukupan pengawasan oleh kreditor (Herwidayatmo, 2003).

\section{Landasan Teori \\ Teori Agensi}

Agency theory disebut juga dengan conducting theory. Agency theory membahas antara lain hubungan keagenan antara principal (pemilik) dan agent (manajemen). Pemilik memberikan kewenangan kepada manajemen untuk mengelola aset perusahaannya. Wolk et.al. (2001) menyatakan asumsi yang melandasi hubungan keagenan adalah tiap-tiap individu (misal baik pemilik maupun manajemen) akan berbuat yang terbaik bagi kepentingan pribadinya (jadi belum tentu terbaik bagi perusahaan) dan perusahaan adalah pusat pertemuan semua pihak yang terlibat dalam hubungan kontrak yang ada antara manajemen, pemilik, kreditor dan pemerintah.

\section{Bisnis Keluarga}

Dalam bisnis, terdapat perbedaan antara family owned enterprise dan family business (The Jakarta Consulting Group, 2014). Meski keduanya dimiliki oleh keluarga, family owned enterprise dikelola oleh anggota keluarga maupun professional, sementara family business dikelola oleh sebagian besar anggota keluarga dan memegang posisi kunci dalam perusahaan. Peran bisnis keluarga penting bukan hanya karena mereka memberikan kontribusi bagi perekonomian, namun juga karena nilai-nilai dan tata kelola yang diperjuangkan. Hal inilah yang membedakan bisnis keluarga dengan bisnis lain.

Corporate Governance akan berbeda pada konteks bisnis keluarga karena tujuan organisasi akan diarahkan pada mensejahterakan keluarga pengendali sebagai pemangku kepentingan yang utama. Keluarga yang mengendalikan kepemilikan perusahaan akan mempengaruhi proses dan struktur governance melalui berbagai level keterlibatan dalam perusahaan. Keterlibatan keluarga dapat dilakukan dengan cara pada level dewan komisaris, level manajemen dan level perusahaan secara keseluruhan (Varquez, et.al, 2019). 


\section{Benturan Kepentingan}

Benturan kepentingan adalah keadaan di mana terdapat konflik antara kepentingan ekonomis Perusahaan dan kepentingan ekonomis pribadi pemegang saham, anggota Dewan Komisaris dan Direksi, serta karyawan Perusahaan (KNKG, 2010).

Menurut Peraturan Menteri Negara BUMN No PER-01/MBU/2011 tentang Penerapan Tata Kelola Perusahaan yang Baik pada BUMN, dijelaskan bahwa anggota Dewan Komisaris/Dewan Pengawas dilarang melakukan tindakan yang mempunyai benturan kepentingan (conflict of interest) dan mengambil keuntungan pribadi, dari pengambilan keputusan dan/atau pelaksanaan kegiatan BUMN yang bersangkutan, selain penghasilan yang sah.

\section{Corporate Governance}

Ada dua sudut pandang dalam mendefinisikan Corporate Governance (CG), yaitu sudut pandang sempit (narrow view) dan luas (broad view). Berdasarkan sudut pandang sempit, CG didefinisikan sebagai hubungan antara perusahaan dengan pemegang saham. Definisi ini ditunjukan dalam teori keagenan. Menurut sudut pandang yang lebih luas, CG merupakan a web of relationship, tidak hanya perusahaan dengan pemilik atau pemegang saham, tetapi juga antara perusahaan dengan stakeholders lain, yaitu karyawan, pelanggan, pemasok, bondholders, dan lainnya. Definisi ini ditunjukan dalam teori stakeholders. Berdasarkan sudut pandang teori stakeholders, Solomon dan Solomon (2004) mendefinisikan CG sebagai suatu sistem checks and balances, baik internal maupun eksternal yang menjamin bahwa perusahaan melaksanakan akuntabilitas kepada seluruh stakeholdersnya dan bertanggung jawab (responsible) secara sosial dalam aktivitas bisnisnya (Solomon \& Solomon, 2004).

CG berkaitan dengan institusi public atau privat termasuk hukum, regulasi, dan praktek-praktek bisnis yang bersama-sama mengatur hubungan antara manajer perusahaan di satu pihak dengan pihak lain yang melakukan investasi sumber (pemilik dana, kreditor, karyawan, dan pemilik sumber kekayaan lainnya yang terwujud maupun tidak)(Oman, 2001). Secara khusus, klasifikasi institusi CG mencakup pembuatan undangundang mengenai penerbitan dan perdagangan sekuritas, lembaga pemerintah yang mengontrol dan mengawasi ketaatan perusahaan terhadap peraturan sekuritas, pasar modal, asosiasi professional, asosiasi bisnis, dan pihak-pihak lain baik privat maupun publik yang mengawasi perusahaan dan perilaku pelaku pasar modal (misalnya agen pemeringkat, media keuangan).

\section{Corporate Governance dan Benturan Kepentingan}

Mekanisme CG berkaitan dengan bentuk konflik yang terjadi dalam korporasi. Bentuk konflik pada awal mulanya terjadi karena pemisahan antara kepemilikan dan pengelolaan perusahaan. Berle dan Means (1932) menyatakan bahwa pengelola perusahaan cenderung untuk mementingkan kepentingannya sendiri dibandingkan dengan kepentingan pemilik modal. Argumentasi Berle dan Means tersebut merupakan awal pengembangan pendekatan keagenan di bidang keuangan, yang sampai saat ini berkembang secara teoritis maupun empiris.

Konflik yang timbul dari hubungan kerja antara dua pihak yaitu pemberi kerja (prinsipal) dan pelaksana (agen) disebabkan dua hal: (1) masalah keagenan yang muncul karena perbedaan tujuan antara prinsipal dengan agen dan mahalnya biaya bagi principal untuk memeriksa apa yang dikerjakan oleh agen, dan (2) masalah risk sharing yang muncul karena perbedaan preferensi risiko antara principal dengan agen. Dengan demikian, prinsipal dan agen melakukan tindakan yang berbeda karena perbedaan preferensi risiko (Eisenhardt, 1989).

Berdasarkan dua bentuk konflik tersebut, Bai, et.al. (2004) mengklasifikasikan dua mekanisme CG yaitu mekanisme internal dan mekanisme eksternal. Mekanisme internal disusun untuk menyamakan kepentingan manajer dengan pemegang saham. Beberapa mekanisme internal yang digunakan untuk tujuan mengendalikan masalh keagenan antara lain: dewan komisaris dan kompensasi eksekutif. Dewan komisaris dipilih dan diangkat oleh pemegang saham dalam Rapat Umum pemegang Saham atau General Meeting of 
Shareholders dan berperan untuk mewakili dan melindungi kepentingan pemegang saham.

\section{Good Corporate Governance}

Setiap perusahaan harus memastikan bahwa asas Good Corporate Governance (GCG) diterapkan pada setiap aspek bisnis dan di semua jajaran perusahaan. Asas GCG yaitu transparansi, akuntabilitas, responsibilitas, independensi serta kewajaran dan kesetaraan diperlukan untuk mencapai kesinambungan usaha (sustainability) perusahaan dengan memperhatikan pemangku kepentingan (stakeholders)(KNKG, 2006).

\section{Dewan Komisaris}

Pasal 1 angka 6 UUPT menjelaskan bahwa ada keharusan bagi setiap Perseroan mempunyai Dewan Komisaris. Dewan Komisaris adalah organ perseroan yang bertugas melakukan pengawasan secara umum dan/atau khusus sesuai dengan anggaran dasar serta memberi nasihat kepada Direksi.

Dalam Undang-Undang Perseroan Terbatas, istilah komisaris meliputi dua pengertian berikut:

a) Pengertian pertama adalah sebagai organ perseroan yang lazimnya dikenal dengan nama dewan komisaris dan anggota Dewan Komisaris. Undang-Undang Perseroan Terbatas memberikan hak sepenuhnya kepada pendiri ataupun pemegang saham perseroan untuk menentukan sendiri wewenang dan kewajiban komisaris dalam perseroan.

b) Pengertian kedua adalah sebagai pelaksana tugas Komisaris. Tugas Komisaris menurut UUPT, yaitu mengawasi kebijaksanaan Direksi dalam menjalankan perseroan serta memberikan nasihat kepada Direksi perseroan.

Hubungan kerja Dewan Komisaris dan Direksi adalah hubungan check and balances secara independen dengan prinsip bahwa kedua badan tersebut mempunyai kedudukan yang setara dan keduanya mempunyai tujuan akhir untuk kemajuan dan kesehatan Perusahaan. Oleh karena itu Dewan Komisaris dan Direksi harus memiliki kesamaan persepsi terhadap visi, misi dan nilai-nilai perusahaan (KNKG, 2010).

\section{Penelitian Terdahulu}

Utami (2007) menganalisa Fungsi dan Peranan Komisaris Independen dalam Perusahaan Go Public di Indonesia. Hasil penelitian menunjukkan bahwa Komisaris Independen mempunyai peranan yang penting dalam perusahaan sekuritas yang telah go public dalam hal mengadakan pengawasan terhadap Direksi dalam melakukan pengelolaan perusahaan dan menetapkan kebijakan strategis perusahaan. Komisaris Independen juga mengevaluasi laporan tahunan yang diberikan oleh Direksi, dengan tujuan untuk memberikan perlindungan yang efektif pada para pemegang saham, stakeholders dan tentunya terhadap kepentingan perusahaan itu sendiri. Hal ini karena Komisaris Independen tidak boleh terafiliasi dengan para pemegang saham dan Direksi perusahaan sehingga dapat memastikan bahwa Direksi telah mengelola dan menjalankan perusahaan berdasarkan prinsip Good Corporate Governance. Selain itu, Komisaris Independen tidak dapat dimintai pertanggung jawaban oleh para pemegang saham perusahaan sekuritas yang dilikuidasi, karena hanya menjalankan fungsi pengawasan. Di lain pihak, Komisaris Independen dapat bertanggung jawab secara pribadi berdasarkan teori Piercing Corporate Veil, dengan ketentuan Komisaris Independen tersebut telah melakukan pelanggaran terhadap fiduciary duties yang dimilikinya terhadap perusahaan dan melakukan kesalahan dalam laporan tahunan kepada publik.

Saputra (2010) menganalisa Peranan Komisaris Independen dalam Mewujudkan Good Corporate Governance (GCG) pada Bank Nagari. Hasil penelitian menunjukkan bahwa Komisaris Independen Bank Nagari, belum melaksanakan peranannya dengan baik untuk mewujudkan Good Corporate Governance (GCG), hal ini dikarenakan dalam pengambilan keputusan oleh dewan komisaris, komisaris independen hanya sebagai penyeimbang dalam pengambil keputusn apabila terjadi suara yang berimbang antara setuju dengan yang tidak setuju. Decision maker tetap pada komisaris utama. Hak veto juga diberikan pada komisaris utama sehingga akan menimbulkan dominasi yang tidak wajar oleh pemegang saham seri $A$. 
Hal ini karena komisaris utama adalah pelaksana dari kepentingan mereka. Selain tiu, hak veto komisaris utama senantiasa memperhatikan kepentingan dari pemegang saham seri A dan mengabaikan kepentingan dari stakeholders lainnya dalam pengambilan keputusan yang mengakibatkan asas kesetaraan dan kewajaran akan jauh panggang dari api.Terakhir, dewan direksi dan dewan komisaris hanya berpedoman pada Anggaran Dasar Bank Nagari dalam melaksanakan tugas dan tanggung jawabnya dan tidak melihat pada Peraturan Bank Indonesia Nomor 8/4/PBI/2006 padahal ini wajib diaplikasikan dalam pengelolaan Bank. Dalam kondisi yang sedemikian, Komisaris Independen berusaha mengingatkan kepada setiap stakeholders untuk berkomitmen dengan penerapan GCG pada Bank Nagari.

Islam (2014) menganalisa Peran dan Tanggung jawab Komisaris Perseroan dalam Mengimplementasi Good Corporate Governance (GCG). Hasil penelitian menunjukkan bahwa peran dewan komisaris sebagai pengawas kinerja direksi dapat berupa: monitoring kinerja keuangan secara rutin, baik cash flow maupun laba rugi secara bulanan, triwulan, semesteran, maupun tahunan; melakukan pengawasan pada kinerja personalia, apakah tugas dan tanggung jawab mereka dijalankan secara baik sesuai dengan SOP; mengawasi cost dan benefit setiap sttuktur organisasi dan melakukan penilaian terhadap hal tersebut. Sedangkan pelaksanaan fungsi penasihat itu sendiri, secara umum dapat berupa: memberikan arahan terhadap penyusunan Rencana Kerja dan Anggaran Perusahaan (RKAP) pada setiap tahunnya. Komisaris dapat memberikan masukan dalam aspek bisnis kepada Direksi dalam rangka penyusunan RKAP; Dewan Komisaris dapat pula memberikan masukan mengenai perbaikan kinerja perseroan pada saat rapat Direksi yang diadakan secara berkala.

\section{Pengembangan Hipotesis}

Teori keagenan menjelaskan pemisahan antara kepemilikan dan manajemen memungkinkan terjadinya masalah keagenan karena adanya perbedaan antara kepentingan pemilik dan manajemen. Kondisi ini dikenal dengan benturan kepentingan. Benturan
Kepentingan adalah keadaan di mana terdapat konflik antara kepentingan ekonomis Perusahaan dan kepentingan ekonomis pribadi pemegang saham, anggota Dewan Komisaris dan Direksi, serta karyawan Perusahaan. Dalam rangka memitigasi benturan kepentingan, setiap anggota Dewan Komisaris dan Direksi serta karyawan Perusahaan yang memiliki wewenang pengambilan keputusan diharuskan setiap tahun membuat pernyataan tidak memiliki benturan kepentingan terhadap setiap keputusan yang telah dibuat olehnya dan telah melaksanakan pedoman perilaku yang ditetapkan oleh Perusahaan (KNKG, 2010).

Dari perspektif teori keagenan, anggota dewan komisaris merupakan representasi atau perwakilan dari para pemegang saham yang dipilih serta bertanggung jawab kepada pemegang saham melalui Rapat Umum Pemegang Saham (RUPS). Dengan amanah tersebut, maka Dewan Komisaris akan memiliki peran sebagai jembatan antara pemegang saham dengan direksi atau pihak eksekutif yang bertanggung jawab terhadap operasionalisasi perusahaan. Fungsi dan peranan dimaksud menjadi semakin penting jika kepemilikan perusahaan dimiliki secara luas dan menyebar (dispersed) pada sejumlah besar pemegang saham. Dalam kondisi kepemilikan tersebar, maka pemilik tidak dapat menggunakan kekuasaan mereka dalam mengintervensi, mengawasi dan memastikan kinerja manajerial Direksi (Lukviarman, 2016).

Hubungan kerja Dewan Komisaris dan

Direksi adalah hubungan check and balances secara independen dengan prinsip bahwa kedua badan tersebut mempunyai kedudukan yang setara dan keduanya mempunyai tujuan akhir untuk kemajuan dan kesehatan Perusahaan (KNKG, 2010). Oleh karena itu, Dewan Komisaris harus memenuhi syarat kemampuan dan integritas sehingga pelaksanaan fungsi pengawasan dan pemberian nasihat untuk kepentingan Perusahaan dapat dilaksanakan dengan baik. Selain itu, anggota Dewan Komisaris dilarang memanfaatkan Perusahaan untuk kepentingan pribadi, keluarga, kelompok usahanya dan atau pihak lain.

Dengan kata lain, Dewan Komisaris sebaiknya tidak memiliki hubungan afiliasi 
sehingga memungkinkan tidak terjadinya benturan kepentingan. Yang dimaksud dengan terafiliasi adalah pihak yang mempunyai hubungan bisnis dan keluarga dengan pemegang saham pengendali, anggota Direksi dan Dewan Komisaris lain, serta dengan Perusahaan itu sendiri. Bahkan dalam konteks Komisaris Independen, komisaris yang tidak terafiliasi berarti bebas dari segala kepentingan dan kegiatan bisnis atau hubungan lain dengan pemegang saham pengendali dan/atau perusahaan terafiliasi dengan pemegang saham pengendali, yang dapat diintepretasikan akan menghalangi atau mengurangi kemampuan Komisaris Independen untuk bertindak dan berpikir independen demi kepentingan Perusahaan. Dengan kata lain, independensi dapat memastikan pelaksanaan fungsi pengawasan komisaris dapat efektif dan terlaksana dengan baik.

Berdasarkan penjabaran diatas, maka dikembangkan hipotesis penelitian:

$\mathrm{H}_{1}$ : Peran Affiliated Commissioner dalam Penerapan Good Corporate Governance pada Aspek Transparansi

$\mathrm{H}_{2}$ : Peran Affiliated Commissioner dalam Penerapan Good Corporate Governance pada Aspek Akuntabilitas

$\mathrm{H}_{3}$ : Peran Affiliated Commissioner dalam Penerapan Good Corporate Governance pada Aspek Pertanggungjawaban

$\mathrm{H}_{4}$ : Peran Affiliated Commissioner dalam Penerapan Good Corporate Governance pada Aspek Independensi

$\mathrm{H}_{5}$ : Peran Affiliated Commissioner dalam Penerapan Good Corporate Governance pada Aspek Kewajaran

\section{Metode Penelitian}

Penelitian merupakan suatu kegiatan ilmiah yang didasarkan pada metode, sistematika dan pemikiran tertentu yang bertujuan untuk mempelajari satu atau beberapa gejala hukum tertentu, dengan jalan menganalisanya. Pendekatan yang digunakan dalam penelitian ini adalah normatif-empiris dimana merupakan gabungan antara pendekatan hukum normatif dengan adanya penambahan berbagai unsur empiris. Metode penelitian normatif-empiris mengenai implementasi ketentuan hukum normatif (undang-undang) dalam aksinya pada setiap peristiwa hukum tertentu yang terjadi dalam suatu masyarakat (Soekanto, 2007).

\section{Populasi dan Sampel Penelitian}

Populasi Penelitian adalah Perusahaan Bisnis Keluarga yang terdaftar pada Bursa Efek Indonesia pada periode tahun 2018. Penelitian ini menggunakan purposive sampling dimana harus ada affiliated commissioner yang menjabat pada tahun 2018. Dari hasil sampling tersebut, maka didapatkan 18 perusahaan emiten yang memenuhi syarat yaitu ACES, ADRO, AMRT, BIRD, BRPT, CTRA, INCI, KBLM, KPIG, MNCN, MYOR, PTSN, PWON, SIDO, SONA, SPMA, SRAJ dan WIIM.

\section{Variabel Operasional Penelitian}

Variabel yang diteliti pada peran Dewan Komisaris adalah aspek-aspek Good Corporate Governance yaitu transparansi, akuntabilitas, pertanggungjawaban, kemandirian dan kewajaran.

Berdasarkan tabel indikator-indikator dewan komisaris (lampiran 1), maka dirumuskan pengukuran Good Corporate Governance pada Dewan Komisaris sebagai berikut:

1) Transparansi (transparency) adalah keterbukaan dalam melaksanakan proses pengambilan keputusan dan keterbukaan dalam mengungkapkan informasi material dan relevan mengenai perusahaan. Indikatorindikator yang mewakili aspek transparansi pada Dewan Komisaris yaitu:

a) Pengungkapan jumlah kehadiran rapat dewan komisaris baik dewan komisaris sendiri maupun dengan dewan direksi

b) Pengungkapan afiliasi

c) Pengungkapan benturan kepentingan

d) Pengungkapan informasi kepemilikan saham serta anggota keluarga

e) Pengungkapan renumerasi dan fasilitas

f) Pengungkapan Kinerja tugas Dewan Komisaris

2) Akuntabilitas (accountability) adalah kejelasan fungsi, pelaksanaan dan pertanggungjawaban organ perseroan sehingga pengelolaan perusahaan terlaksana secara efektif; Indikator-indikator yang 
mewakili aspek akuntabilitas pada Dewan Komisaris yaitu:

a) Latar belakang bidang keuangan dan asuransi bagi anggota Dewan Komisaris

b) Fit dan Proper Test Anggota Komisaris

c) Proses pemilihan Presiden Komisaris

3) Pertanggungjawaban (responsibility) adalah kesesuaian di dalam pengelolaan perusahaan terhadap peraturan perundang-undangan dan prinsip-prinsip korporasi yang sehat. Indikatorindikator yang mewakili aspek pertanggungjawaban pada Dewan Komisaris yaitu:

a) Pengawasan dan pemberian nasihat sesuai Anggaran Dasar

b) Pengawasan atas kebijakan pengurusan, jalanya pengurusan Perseroan dan pemberi nasihat utk kepentingan Perseroan

c) Pengawasan dan pemberian nasihat dengan itikad baik, kehatian-hatian dan penuh tanggung jawab.

d) Terdapat Laporan Pengawasan Dewan Komisaris dalam RUPS

e) Penelaahan Laporan Tahunan

f) Penanda tanganan Laporan Tahunan

4) Independensi (independency) adalah keadaan di mana perusahaan dikelola secara professional tanpa benturan kepentingan dan pengaruh/tekanan dari pihak manapun yang tidak sesuai dengan peraturan perundangundangan dan prinsip-prinsip korporasi yang sehat. Indikator- indikator yang mewakili aspek Independensi pada Dewan Komisaris yaitu:

a) Mayoritas dewan komisaris tidak ada afiliasi dgn Anggota Direksi atau Komisaris sampai derajat dua. Komposisi Komisaris Independen $20-50 \%$ dari total Dewan Komisaris dengan jumlah minimal dua komisaris.

b) Kode etik Dewan Komisaris perihal Benturan Kepentingan

c) Evaluasi Independensi Dewan Komisaris terhadap Benturan Kepentingan

5) Kewajaran (fairness) adalah keadilan dan kesetaraan di dalam memenuhi hak-hak Pemangku Kepentingan (stakeholders) yang timbul berdasarkan perjanjian dan peraturan perundang-undangan. Indikator-indikator yang mewakili aspek kewajaran pada Dewan Komisaris yaitu:

a) Tidak dapat menjadi kuasa dari Pemegang Saham dalam RUPS

b) Tidak ada rangkap jabatan kecuali hanya pada posisi Komite-Komite atau Perusahaan Publik lain

\section{Hasil dan Pembahasan \\ Pemetaan Independensi Dewan Komisaris pada Perusahaan Bisnis Keluarga}

Bisnis keluarga adalah sebuah bisnis ketika kontrol perusahaan dipegang oleh salah satu dari pendiri, keluarga pendiri, atau pemegang saham pengendahli baru yang membeli saham dari pendiri (Yeh, 2017). Dalam terminologi bisnis ada dua jenis perusahaan keluarga. Pertama adalah perusahaan yang dimiliki keluarga tetapi dikelola oleh eksekutif profesional yang berasal dari luar lingkaran keluarga. Jenis perusahaan keluarga yang kedua adalah perusahaan yang dimiliki dan dikelola oleh anggota keluarga pendirinya (Susanto, 2007). Sampel penelitian yang diteliti dalam penelitian ini adalah jenis perusahaan keluarga yang kedua yaitu adanya keterlibatan anggota keluarga dalam kepemilikan dan manajemen khususnya pada level dewan komisaris.

Berdasarkan tabel 4.1, ditemukan bahwa ada 13 emiten yang memiliki hubungan afiliasi antara Presiden Komisaris dan Presiden Direkur, yaitu ACES, BRPT, CTRA, INCI, KBLM, KPIG, MYOR, PTSN, SIDO, SONA, SPMA, SRAJ dan WIIM. Hal ini berarti bahwa $72 \%$ dari sampel penelitian menunjukkan adanya control-enhanced mechanism yang cukup besar karena terkait dengan pimpinan masingmasing dewan baik direksi maupun komisaris dimana sangat penting dalam pengambilan keputusan perusahan dalam hal pengawasan dan manajemen perusahaan.

Selain itu, ditemukan bahwa ada 11 emiten yang memiliki hubungan afiliasi antara Dewan Komisaris dan Dewan Direksi lebih dari 2 orang, yaitu ACES, AMRT, BIRD, CTRA, KPIG, MYOR, PWON, SIDO, SONA, SPMA dan SRAJ. Hal ini berarti bahwa $61 \%$ dari sampel penelitian menunjukkan adanya dominasi yang besar dalam manajemen perusahaan bisnis 
keluarga dimana diharapkan adanya overall

firm involvment dalam perusahaan. keluarga:

Berikut ini adalah penjabaran keterlibatan anggota dalam manajemen perusahaan bisnis

Tabel 1

Hubungan Afiliasi pada Perusahaan Bisnis Keluarga yang terdaftar pada Bursa Efek Indonesia tahun 2018

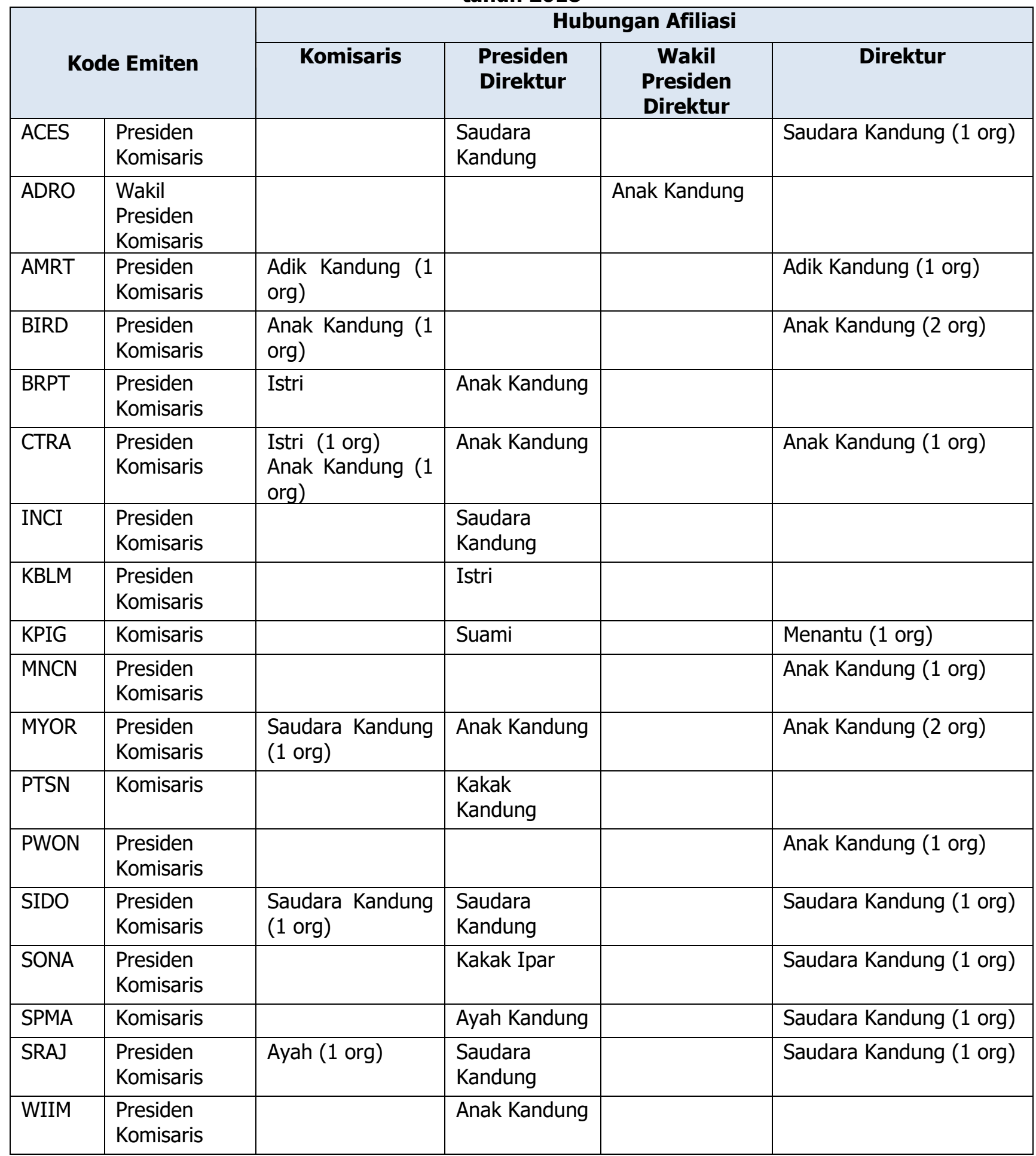

Sumber: Laporan Tahunan 2018

Dan juga, ditemukan bahwa ada family involvement dalam pimpinan dewan komisaris 
sebesar $78 \%$ dari sampel penelitian yaitu 14 emiten. Ini menunjukkan adanya preferensi keterlibatan anggota keluarga dalam posisi tertinggi dalam fungsi pengawasan atas kinerja manajemen perusahaan. Preferensi ini dapat mengurangi integritas Dewan Komisaris pada perusahaan tersebut karena peran krusial dewan komisaris sebagai jembatan antara pemegang saham dengan direksi atau pihak eksekutif yang bertanggung jawab terhadap operasionalisasi perusahaan. Hal ini karena adanya kemungkinan benturan kepentingan antara kepentingan keluarga dengan kepentingan pemegang saham minoritas.

\section{Peran Affiliated Commissioner dalam Penerapan Good Corporate Governance pada} Aspek Transparansi

Tabel 2

Aspek Transparansi

\begin{tabular}{|c|c|c|c|c|c|c|c|}
\hline No & $\begin{array}{c}\text { Kode } \\
\text { Emiten }\end{array}$ & $\begin{array}{c}\text { Kehadiran } \\
\text { Rapat }\end{array}$ & Afiliasi & $\begin{array}{c}\text { Benturan } \\
\text { Kepentingan }\end{array}$ & $\begin{array}{c}\text { Kepemilikan } \\
\text { Saham }\end{array}$ & \begin{tabular}{|c|}
$\begin{array}{c}\text { Renumerasi dan } \\
\text { Fasilitas }\end{array}$ \\
\end{tabular} & $\begin{array}{c}\text { Kinerja } \\
\text { Komisaris }\end{array}$ \\
\hline 1 & ACES & $x$ & $x$ & $x$ & $\sqrt{ }$ & $x$ & $x$ \\
\hline 2 & ADRO & $\sqrt{ }$ & $\sqrt{ }$ & $x$ & $\sqrt{ }$ & $\sqrt{ }$ & $\sqrt{ }$ \\
\hline 3 & AMRT & $\sqrt{ }$ & $\sqrt{ }$ & $x$ & $\sqrt{ }$ & $\sqrt{ }$ & $\sqrt{ }$ \\
\hline 4 & BIRD & $\sqrt{ }$ & $\sqrt{ }$ & $\sqrt{ }$ & $\sqrt{ }$ & $\sqrt{ }$ & $x$ \\
\hline 5 & BRPT & $\sqrt{ }$ & $x$ & $x$ & $\sqrt{ }$ & $\sqrt{ }$ & $\sqrt{ }$ \\
\hline 6 & CTRA & $\sqrt{ }$ & $\sqrt{ }$ & $\sqrt{ }$ & $\sqrt{ }$ & $\sqrt{ }$ & $x$ \\
\hline 7 & INCI & $x$ & $x$ & $\sqrt{ }$ & $\sqrt{ }$ & $x$ & $\sqrt{ }$ \\
\hline 8 & KBLM & $x$ & $x$ & $x$ & $\sqrt{ }$ & $\sqrt{ }$ & $\sqrt{ }$ \\
\hline 9 & KPIG & $\sqrt{ }$ & $\sqrt{ }$ & $x$ & $\sqrt{ }$ & $\sqrt{ }$ & $\sqrt{ }$ \\
\hline 10 & MNCN & $\sqrt{ }$ & $\sqrt{ }$ & $x$ & $\sqrt{ }$ & $\sqrt{ }$ & $x$ \\
\hline 11 & MYOR & $x$ & $\sqrt{ }$ & $x$ & $\sqrt{ }$ & $\sqrt{ }$ & $x$ \\
\hline 12 & PTSN & $\sqrt{ }$ & $\sqrt{ }$ & $\sqrt{ }$ & $\sqrt{ }$ & $\sqrt{ }$ & $\sqrt{ }$ \\
\hline 13 & PWON & $\sqrt{ }$ & $\sqrt{ }$ & $\sqrt{ }$ & $\sqrt{ }$ & $\sqrt{ }$ & $x$ \\
\hline 14 & SIDO & $x$ & $\sqrt{ }$ & $x$ & $x$ & $\sqrt{ }$ & $x$ \\
\hline 15 & SONA & $x$ & $\sqrt{ }$ & $x$ & $\sqrt{ }$ & $\sqrt{ }$ & $\sqrt{ }$ \\
\hline 16 & SPMA & $x$ & $\sqrt{ }$ & $x$ & $\sqrt{ }$ & $\sqrt{ }$ & $x$ \\
\hline 17 & SRAJ & $x$ & $x$ & $x$ & $x$ & $\sqrt{ }$ & $x$ \\
\hline 18 & WIIM & $\sqrt{ }$ & $x$ & $\sqrt{ }$ & $\sqrt{ }$ & $\sqrt{ }$ & $X$ \\
\hline & Total & 10 & 12 & 6 & 16 & 16 & \\
\hline
\end{tabular}

Sumber: Laporan Tahunan (2018)

Pada tabel 4.2 ditemukan bahwa hanya 1 emiten yaitu PTSN yang mengungkap semua item yang terkait aspek transparansi dalam laporan tahunan perusahaan tahun 2018. Selain itu, perusahaan sampel penelitian cenderung mengungkapkan jumlah kehadiran rapat Dewan Komisaris, hubungan afiliasi antara dewan komisaris dan dewan direksi, kepemilikan saham perusahaan oleh dewan komisaris dan renumerasi \& fasilitas yang diterima oleh dewan komisaris dimana terdapat minimal 10 dari 18 emiten yang mengungkapkannya.

Permen BUMN Per -01 MBU $2011 \mathrm{ttg}$ GCG BUMN Pasal 15 ayat 1 sampai menyatakan bahwa:

1) RUPS wajib menetapkan Indikator Pencapaian Kinerja (Key Performance Indicators) Dewan Komisaris/Dewan 
Pengawas berdasarkan usulan dari Dewan Komisaris/Dewan Pengawas yang bersangkutan.

2) Indikator Pencapaian Kinerja merupakan ukuran penilaian atas keberhasilan pelaksanaan tugas dan tanggung jawab pengawasan dan pemberian nasihat oleh Dewan Komisaris/Dewan Pengawas sesuai dengan ketentuan peraturan perundangundangan dan/atau anggaran dasar:

3) Dewan Komisaris/Dewan Pengawas wajib menyampaikan laporan triwulanan perkembangan realisasi Indikator Pencapaian Kinerja kepada para Pemegang Saham/Menteri.

Namun, hanya ditemukan baru 8 emiten perusahaan yang mengungkapkan penilaian kinerja dewan komisaris dan pencapaiannya. Dengan kurangnya pengungkapan ini dalam keseluruhan sampel penelitian menunjukkan bahwa $56 \%$ perusahaan bisnis keluarga tidak melakukan penilaian kinerja terhadap komisaris yang juga terafiliasi dengan dewan direksi perusahaan. Kecenderungan negatif ini juga diperkuat bahwa hanya 6 emiten yang mengungkap transaksi benturan kepentingan yang terkait dengan dewan komisaris. Hal ini menunjukkan dengan adanya hubungan afiliasi yang kuat antara dewan komisaris dan dewan direksi dalam sampel penelitian ini menyebabkan kurangnya transparansi pada perusahaan keluarga terkait kepentingan keluarga dalam perseroan.

\section{Peran Affiliated Commissioner dalam Penerapan Good Corporate Governance pada Aspek Akuntabilitas}

Tabel 3

Aspek Akuntabilitas

\begin{tabular}{|c|c|c|c|c|}
\hline No & $\begin{array}{c}\text { Kode } \\
\text { Emiten }\end{array}$ & $\begin{array}{c}\text { Financial } \\
\text { Background }\end{array}$ & $\begin{array}{c}\text { Fit \& Proper Test } \\
\text { Anggota Komisaris }\end{array}$ & $\begin{array}{c}\text { Proses Pemilihan } \\
\text { Presiden Komisaris }\end{array}$ \\
\hline 1 & ACES & $x$ & $x$ & $X$ \\
\hline 2 & ADRO & $\sqrt{ }$ & $x$ & $x$ \\
\hline 3 & AMRT & $x$ & $x$ & $x$ \\
\hline 4 & BIRD & $\sqrt{ }$ & $\sqrt{ }$ & $x$ \\
\hline 5 & BRPT & $\sqrt{ }$ & $x$ & $x$ \\
\hline 6 & CTRA & $\sqrt{ }$ & $x$ & $X$ \\
\hline 7 & INCI & $\sqrt{ }$ & $x$ & $x$ \\
\hline 8 & KBLM & $x$ & $x$ & $x$ \\
\hline 9 & KPIG & $x$ & $x$ & $x$ \\
\hline 10 & MNCN & $X$ & $x$ & $X$ \\
\hline 11 & MYOR & $\sqrt{ }$ & $x$ & $x$ \\
\hline 12 & PTSN & $\sqrt{ }$ & $x$ & $X$ \\
\hline 13 & PWON & $x$ & $x$ & $X$ \\
\hline 14 & SIDO & $x$ & $x$ & $x$ \\
\hline 15 & SONA & $\sqrt{ }$ & $x$ & $x$ \\
\hline 16 & SPMA & $x$ & $x$ & $x$ \\
\hline 17 & SRAJ & $X$ & $x$ & $x$ \\
\hline 18 & WIIM & $\sqrt{ }$ & $x$ & $X$ \\
\hline \multicolumn{2}{|r|}{ Total } & 9 & 1 & 0 \\
\hline
\end{tabular}

Sumber: Laporan Tahunan (2018) 
Pada tabel 4.3 ditemukan bahwa hanya 9 emiten yang memiliki minimal 1 (satu) anggota Dewan Komisaris dengan latar belakang pendidikan atau pengalaman kerja terkait dengan keuangan. Hal ini menunjukkan sebagian dari sampel perusahaan tidak memiliki kompetensi yang tepat dan seharusnya pada Dewan Komisaris untuk melakukan fungsi pengawasannya dalam aspek audit keuangan yang tertera pada UU No 40 Tahun 2007 tentang Perseroan Terbatas Pasal 66 ayat 1, yang berbunyi "Direksi menyampaikan laporan tahunan kepada RUPS setelah ditelaah oleh Dewan Komisaris dalam jangka waktu paling lambat 6 (enam) bulan setelah tahun buku Perseroan berakhir." Dalam melakukan penelaahan laporan tahunan, Dewan Komisaris juga mengevaluasi laporan keuangan perusahaan. Hal ini sesuai dengan UU No 40 Tahun 2007 Pasal 69 ayat 4 yang berbunyi "Persetujuan laporan tahunan termasuk pengesahan laporan keuangan serta laporan tugas pengawasan Dewan Komisaris dilakukan oleh RUPS."

Peraturan Bank Indonesia No 8 tahun 2006 tentang Good Corporate Governance bagi bank umum Pasal 6 ayat 2 menyatakan bahwa Anggota dewan Komisaris harus memenuhi persyaratan telah lulus. Penilaian Kemampuan dan Kepatutan (Fit and Proper Test) sesuai dengan ketentuan Bank Indonesia tentang
Penilaian Kemampuan dan Kepatutan ( Fit and Proper Test). Hal ini menunjukkan pentingnya proses Penilaian Kemampuan dan Kepatutan anggota dewan komisaris terkait dengan aspek akuntabilitas. Namun 18 emiten tidak mengungkap uraian terkait dengan proses Fit \& Proper Test dalam Laporan Tahunan.

Walaupun hampir semua emiten mencantumkan bahwa pemilihan anggota Komisaris telah disesuaikan dengan Peraturan Otoritas Jasa Keuangan No.33/POJK.04/2014 Pasal 35 terkait Pedoman dan Kode Etik. Namun, peraturan tersebut tidak membahas proses Fit \& Proper Test bagi anggota komisaris. Dengan kata lain, hampir semua emiten dalam sampel penelitian yaitu 17 emiten tidak melakukan proses Fit \& Proper Test dalam pemilihan anggota komisaris. Hal ini sama juga terjadi pada proses pemilihan Presiden Komisaris dimana tidak ada uraian prosedur untuk pemilihan posisi tersebut. Fakta ini sesuai dengan data yang dipaparkan dalam Tabel 4.1 dimana ada 14 emiten perusahaan yang dipimpin oleh affiliated commissioner. Ketidak jelasan aturan atau prosedur pemilihan baik anggota komisaris dan presiden komisaris menunjukkan akuntabilitas anggota komisaris dipertanyakan dalam melakukan fiduciary duties terhadap direksi perusahaan.

\section{Peran Affiliated Commissioner dalam Penerapan Good Corporate Governance pada Aspek Pertanggungjawaban}

Tabel 4

Aspek Pertanggung Jawaban

\begin{tabular}{|l|l|c|c|c|c|c|}
\hline NoEmiten & $\begin{array}{l}\text { Kode } \\
\text { Pengawasan }\end{array}$ & $\begin{array}{l}\text { Pemberian } \\
\text { Nasihat }\end{array}$ & $\begin{array}{l}\text { Ada Laporan } \\
\text { Pengawasan dalam } \\
\text { RUPS }\end{array}$ & $\begin{array}{l}\text { Penelaahan } \\
\text { Laporan } \\
\text { Tahunan }\end{array}$ & $\begin{array}{l}\text { Menanda } \\
\text { tangani Laporan } \\
\text { Tahunan }\end{array}$ \\
\hline 1 & ACES & $\sqrt{ }$ & $\mathrm{X}$ & $\sqrt{ }$ & $\mathrm{X}$ & $\sqrt{ }$ \\
\hline 2 & ADRO & $\sqrt{ }$ & $\mathrm{X}$ & $\mathrm{X}$ & $\mathrm{X}$ & $\mathrm{X}$ \\
\hline 3 & AMRT & $\sqrt{ }$ & $\sqrt{ }$ & $\sqrt{ }$ & $\mathrm{X}$ & $\mathrm{V}$ \\
\hline 4 & BIRD & $\sqrt{ }$ & $\sqrt{ }$ & $\sqrt{ }$ & $\mathrm{V}$ & $\sqrt{ }$ \\
\hline 5 & BRPT & $\sqrt{ }$ & $\sqrt{ }$ & $\mathrm{X}$ & $\sqrt{ }$ \\
\hline 6 & CTRA & $\sqrt{ }$ & $\sqrt{ }$ & $\sqrt{ }$ & $\sqrt{ }$ & $\sqrt{ }$ \\
\hline 7 & INCI & $\sqrt{ }$ & $\sqrt{ }$ & $\mathrm{V}$ & $\sqrt{ }$ & $\mathrm{V}$ \\
\hline 8 & KBLM & & $\sqrt{ }$ & & & $\sqrt{ }$ \\
\hline 9 & KPIG & & & & & \\
\hline
\end{tabular}




\begin{tabular}{|c|c|c|c|c|c|}
\hline \begin{tabular}{|l} 
Kode \\
No Emiten
\end{tabular} & $\begin{array}{l}\text { Penjabaran } \\
\text { Pengawasan }\end{array}$ & $\begin{array}{l}\text { Pemberian } \\
\text { Nasihat }\end{array}$ & $\begin{array}{l}\text { Ada Laporan } \\
\text { Pengawasan dalam } \\
\text { RUPS }\end{array}$ & $\begin{array}{l}\text { Penelaahan } \\
\text { Laporan } \\
\text { Tahunan } \\
\end{array}$ & $\begin{array}{l}\text { Menanda } \\
\text { tangani Laporan } \\
\text { Tahunan }\end{array}$ \\
\hline 10 MNCN & $\sqrt{ }$ & $x$ & $\sqrt{ }$ & $x$ & $\sqrt{ }$ \\
\hline 11 MYOR & $\sqrt{ }$ & $\sqrt{ }$ & $\sqrt{ }$ & $x$ & $\sqrt{ }$ \\
\hline 12 PTSN & $\sqrt{ }$ & $\sqrt{ }$ & $\sqrt{ }$ & $X$ & $\sqrt{ }$ \\
\hline 13 PWON & $\sqrt{ }$ & $x$ & $\sqrt{ }$ & $x$ & $\sqrt{ }$ \\
\hline 14 SIDO & $\sqrt{ }$ & $\sqrt{ }$ & $x$ & $x$ & $x$ \\
\hline 15 SONA & $\sqrt{ }$ & $\sqrt{ }$ & $\sqrt{ }$ & $x$ & $\sqrt{ }$ \\
\hline 16 SPMA & $\sqrt{ }$ & $\sqrt{ }$ & $x$ & $x$ & $x$ \\
\hline 17 SRAJ & $\sqrt{ }$ & $\sqrt{ }$ & $\sqrt{ }$ & $x$ & $\sqrt{ }$ \\
\hline 18 WIIM & $\sqrt{ }$ & $x$ & $\sqrt{ }$ & $x$ & $\sqrt{ }$ \\
\hline Total & 18 & 11 & 14 & 3 & 14 \\
\hline
\end{tabular}

Sumber: Laporan Tahunan (2018)

Pada tabel 4 ditemukan bahwa minimal peran dewan komisaris pada 14 emiten berjalan dengan baik dalam hal pengawasan dimana ada penjabaran proses pengawasan yang dilakukan dan disahkannya laporan pengawasan dewan komisaris dalam RUPS. Di lain pihak, adanya disfungsi dalam aspek audit yang terkait penelaahan laporan tahunan dimana ada 14 komisaris emiten yang menanda tangani laporan tahunan namun hanya 3 emiten yang mengungkapkan adanya penelaahan laporan tahunan. Jadi, dapat disimpulkan bahwa fungsi affiliated commissioner yang terkait penelaahan laporan tahunan tidak maksimal. Padahal laporan tahunan mencakup informasi perusahaan secara keseluruhan seperti kilas kinerja tahun berjalan, laporan manajemen, profil perusahaan, analisa diskusi manajemen, penerapan tata kelola perusahaan, pengembangan keberlanjutan, pertanggung jawaban manajemen dan laporan keuangan konsolidasian.

\section{Peran Affiliated Commissioner dalam Penerapan Good Corporate Governance pada Aspek Independensi}

Tabel 5

Aspek Independensi

\begin{tabular}{|c|c|c|c|c|}
\hline No & $\begin{array}{c}\text { Kode } \\
\text { Emiten }\end{array}$ & $\begin{array}{c}\text { Mayoritas Komisaris tidak } \\
\text { ada hubungan afiliasi (20- } \\
\mathbf{5 0 \% )}\end{array}$ & $\begin{array}{c}\text { Kode Etik terkait } \\
\text { Benturan Kepentingan }\end{array}$ & $\begin{array}{c}\text { Evaluasi Independensi } \\
\text { terhadap Benturan } \\
\text { Kepentingan }\end{array}$ \\
\hline 1 & ACES & $50 \%$ & $X$ & $X$ \\
\hline 2 & ADRO & $40 \%$ & $X$ & $X$ \\
\hline 3 & AMRT & $40 \%$ & $X$ & $\checkmark$ \\
\hline 4 & BIRD & $37.5 \%$ & $X$ & $\checkmark$ \\
\hline 5 & BRPT & $33.3 \%$ & $X$ & $X$ \\
\hline 6 & CTRA & $37.5 \%$ & $X$ & $\checkmark$ \\
\hline 7 & INCI & $33.3 \%$ & $X$ & $X$ \\
\hline 8 & KBLM & $66.6 \%$ & $X$ & $X$ \\
\hline 9 & KPIG & $40 \%$ & & $\sqrt{ }$ \\
\hline
\end{tabular}


Jurnal Ekonomi : Journal of Economic p-ISSN 2087-8133| e-ISSN : 2528-326X

\begin{tabular}{|c|c|c|c|c|}
\hline No & $\begin{array}{c}\text { Kode } \\
\text { Emiten }\end{array}$ & $\begin{array}{c}\text { Mayoritas Komisaris tidak } \\
\text { ada hubungan afiliasi (20- } \\
\mathbf{5 0 \% )}\end{array}$ & $\begin{array}{c}\text { Kode Etik terkait } \\
\text { Benturan Kepentingan }\end{array}$ & $\begin{array}{c}\text { Evaluasi Independensi } \\
\text { terhadap Benturan } \\
\text { Kepentingan }\end{array}$ \\
\hline 10 & MNCN & $33.3 \%$ & $\mathrm{X}$ & $\sqrt{ }$ \\
\hline 11 & MYOR & $40 \%$ & $\mathrm{X}$ & $\sqrt{ }$ \\
\hline 12 & PTSN & $33.3 \%$ & $\mathrm{X}$ & $\mathrm{X}$ \\
\hline 13 & PWON & $33.3 \%$ & $\mathrm{X}$ & $\mathrm{X}$ \\
\hline 14 & SIDO & $40 \%$ & $\mathrm{X}$ & $\mathrm{X}$ \\
\hline 15 & SONA & $50 \%$ & $\mathrm{X}$ & $\mathrm{X}$ \\
\hline 16 & SPMA & $60 \%$ & $\mathrm{X}$ & $\mathrm{X}$ \\
\hline 17 & SRAJ & $40 \%$ & $\mathrm{X}$ & $\mathrm{X}$ \\
\hline 18 & WIIM & $33.3 \%$ & 0 & 7 \\
\hline & Total & 18 & & \\
\hline
\end{tabular}

Sumber: Laporan Tahunan (2018)

Pada tabel 5 ditemukan bahwa tidak ada emiten yang menjabarkan kode etik benturan kepentingan dalam laporan tahunan perusahaan. Walaupun sebagian besar emiten mereferensi pada piagam dewan komisaris yang telah disesuaikan dengan Peraturan Otoritas Jasa Keuangan No.33/POJK.04/2014 dimana benturan kepentingan terkait dengan Pasal 13, 15 dan 36. Penjabaran kode etik benturan kepentingan dalam laporan tahunan masih diperlukan karena dapat memberikan rincian dan detail atas rambu-rambu yang harus dipatuhi oleh seluruh pemangku kepentingan perusahaan terkait benturan kepentingan. Hal ini sesuai dengan Permen BUMN Per -01 MBU 2011 tentang Good Corporate Governance BUMN Pasal 17 yang menyatakan bahwa Anggota Dewan Komisaris/Dewan Pengawas dilarang melakukan tindakan yang mempunyai benturan kepentingan (conflict of interest) dan mengambil keuntungan pribadi, dari pengambilan keputusan dan/atau pelaksanaan kegiatan BUMN yang bersangkutan, selain penghasilan yang sah.

Selain itu, 18 emiten telah memenuhi minimal persentase komisaris independen terhadap total anggota dewan komisaris sebesar 20\%. Hal ini sesuai dengan Permen BUMN Per -01 MBU 2011 ttg GCG BUMN Pasal 13 ayat 1 yang berbunyi "Dalam komposisi Dewan Komisaris/Dewan Pengawas, paling sedikit 20\% (dua puluh persen) merupakan anggota Dewan Komisaris/Dewan Pengawas
Independen yang ditetapkan dalam keputusan pengangkatannya." Selain itu, juga memenuhi batas minimal persentase komisaris independen sebesar $30 \%$ yaitu berdasarkan Peraturan OJK No. 33/POJK.04/2014 Pasal 20 ayat 3, yang berbunyi "Dalam hal Dewan Komisaris terdiri lebih dari 2 (dua) orang anggota Dewan Komisaris, jumlah Komisaris Independen wajib paling kurang 30\% (tiga puluh persen) dari jumlah seluruh anggota Dewan Komisaris."

Walaupun semua emiten pada sampel penelitian telah memenuhi batas minimal sesuai dengan peraturan yang berlaku, namun hal ini berbanding terbalik dengan pengungkapan atas kebijakan terkait evaluasi independensi anggota dewan komisaris terhadap potensi benturan kepentingan dimana hanya dilakukan oleh 7 emiten saja. Padahal evaluasi tersebut diwajibkan sesuai dengan pedoman Tata Kelola yang diterbitkan oleh Bursa Efek Indonesia dimana halaman 12 poin d menayatakan bahwa Dewan Komisaris memiliki mekanisme evaluasi independensi anggota Dewan Komisaris dari potensi benturan kepentingan. Fakta ini memberikan kesan adanya aspek formalitas dalam pemenuhan batas minimal persentase independesi dalam dewam komisaris. Pemenuhan yang bersifat formalitas dapat menunjukkan bahwa kurangnya independensi secara intrinsik pada jajaran dewan komisaris. Hal ini dapat menyebabkan fiduciary duties yang terkait pengawasan dan pemberi nasihat 
tidak diterapkan dengan baik atau mungkin dapat menimbulkan disfungsi dari komisaris independen karena adanya kontrol dari affiliated commissioner yang mendominasi dalam sampel penelitian sebagai pimpinan komisaris.

\section{Peran Affiliated Commissioner dalam Penerapan Good Corporate Governance pada Aspek Kewajaran}

Tabel 6

Aspek Kewajaran

\begin{tabular}{|c|c|c|c|}
\hline No & Kode Emiten & $\begin{array}{l}\text { Tidak menjadi Kuasa untuk } \\
\text { Pemegang Saham dalam RUPS }\end{array}$ & $\begin{array}{c}\text { Rangkap Jabatan kecuali pada } \\
\text { Komite/Perusahaan Lain }\end{array}$ \\
\hline 1 & ACES & $\sqrt{ }$ & $x$ \\
\hline 2 & ADRO & $\sqrt{ }$ & $x$ \\
\hline 3 & AMRT & $\sqrt{ }$ & $x$ \\
\hline 4 & BIRD & $\sqrt{ }$ & $x$ \\
\hline 5 & BRPT & $\sqrt{ }$ & $x$ \\
\hline 6 & CTRA & $\sqrt{ }$ & $x$ \\
\hline 7 & INCI & $\sqrt{ }$ & $x$ \\
\hline 8 & KBLM & $\sqrt{ }$ & $x$ \\
\hline 9 & KPIG & $\sqrt{ }$ & $x$ \\
\hline 10 & MNCN & $\sqrt{ }$ & $x$ \\
\hline 11 & MYOR & $\sqrt{ }$ & $x$ \\
\hline 12 & PTSN & $\sqrt{ }$ & $x$ \\
\hline 13 & PWON & $\sqrt{ }$ & $x$ \\
\hline 14 & SIDO & $\sqrt{ }$ & $x$ \\
\hline 15 & SONA & $\sqrt{ }$ & $x$ \\
\hline 16 & SPMA & $\sqrt{ }$ & $x$ \\
\hline 17 & SRAJ & $\sqrt{ }$ & $x$ \\
\hline 18 & WIIM & $\sqrt{ }$ & $x$ \\
\hline \multicolumn{2}{|r|}{ Total } & 18 & 0 \\
\hline
\end{tabular}

Sumber: Laporan Tahunan (2018)

Pada tabel 4.6 ditemukan bahwa semua emiten memenuhi aspek kewajaran (fairness) karena tidak ada yang menjadi kuasa atas pemegang saham dalam RUPS dan tidak adanya rangkap jabatan dalam jajaran direksi. Berdasarkan Peraturan OJK No. 33/POJK.04/2014 Pasal 24 dinyatakan bahwa anggota komisaris tidak dapat merangkap sebagai anggota direksi. Namun di ijinkan menjabat sebagai direksi/komisaris pada perusahaan publik lainnya dan menjabat sebagai anggota komite pada perusahaan publik yang bersangkutan.
Aspek kewajaran menunjukkan tidak adanya perlakuan yang berbeda terhadap pemegang saham manapun dengan tidak menjadi kuasa dari salah satu mereka dalam RUPS. Selain itu, aspek kewajaran menunjukkan bahwa tidak adanya pengecualian terhadap anggota komisaris dalam melakukan rangkap jabatan di luar peraturan yang berlaku.

\section{Simpulan}

Hasil penelitian menunjukkan bahwa penerapan Good Corporate Governance dalam affiliated Commissioner cukup baik dalam aspek Pertanggung jawaban (Responsibility) 
dan Kewajaran (Fairness). Hal ini terbukti dengan tidak adanya rangkap jabatan dalam dewan direksi dan adanya penjabaran pengawasan dan pemberian nasihat pada mayoritas emiten dalam sampel penelitian sesuai dengan UUPT pasal 1 angka 6. Namun, affiliated commissioner tidak menerapkan aspek transparansi, akuntabilitas dan independensi. Hal ini terbukti dengan kurangnya pengungkapan terkait benturan kepentingan baik dalam hal transaksi maupun kode etik yang berlaku. Bahkan hanya 7 (tujuh) emiten yang melakukan evaluasi independensi terkait benturan kepentingan. Selain itu, hanya 1 emiten yang mengungkap semua informasi terkait kinerja dewan komisaris seperti jumlah kehadiran rapat, hubungan afiliasi antara dewan komisaris dan dewan direksi, kepemilikan saham perusahaan oleh dewan komisaris dan renumerasi \& fasilitas yang diterima oleh dewan komisaris. Terakhir, hanya 1 emiten yang mengungkap proses Fit and Proper Test dalam pemilihan anggota komisaris dan prosedur pemilihan presiden komisaris sehingga akuntabilitas anggota komisaris dalam Perusahaan Keluarga terkesan kurang dan dipertanyakan kompetensinya.

\section{Saran}

Dalam penelitian selanjutnya, pengukuran Good Corporate Governance dapat ditambahkan beberapa pengukuran ASEAN Governance Scorecard yang mencakup rincian aspek-aspek yang perlu dilakukan dalam pengawasan seperti kontrol keuangan, kinerja operasional, manajemen risiko, pengendalian internal dan penilaian kinerja direksi. Dengan adanya peraturan yang mendetail terkait pengawasan Dewan Komisaris, maka peran Dewan Komisaris dapat menenuhi aspek fiduciary duties. Hal ini sesuai dengan Teori Stewardship yang menyatakan bahwa para eksekutif tidak fokus pada kepentingannya sendiri tetapi bertindak sebagai pelayan melalui meningkatkan keuntungan bagi seluruh organisasi (Davis et.al., 1997).

\section{Daftar Pustaka}

Bai, C.E., Liu, Q., Lu, J., Song, F.M. \& Zhang, J. 2004. Corporate Governance and Market Valuation in China.
Berle, A. \& G. Means, G. (1932). The Modern Corporation and Private Property. New York: Macmillan Publishing Company.

Corruption Perceptions Index (2002). Corruption Perceptions Index 2002.Diakses dari https://www.transparency.org/research/ cpi/cpi 2002/0

Davis, J., Schoorman, F. \& Donaldson,L. 1997, Toward a stewardship theory of management, Academy of Management Review, Vol. 22 No. 1, pp. 20-47.

Eisenhardt, K.M. 1989, Agency Theory: An assessment and review. Academy of Management Review, Volume 14 No 1, 57-74

Ferramosca, S. \& Ghio, A. 2017, Accounting Choices in Family Firms-An Analysis of Influences and Implications. Springer International Publishing AG.

Frasl, E.J. \& Rieger, H. 2007, Family Business Handbuch: Zukunftssicherung von Familienunternehmen uber Generationen. Linde, Wien.

Heck, R.K.Z. \& Trent, E.S. 1999, The prevalence of family business from a household sample. Family Business Review Volume 12 No 3, hlm 209-219.

Herwidayatmo, 2003, Implementasi Good Corporate Governance untuk perusahaan publik Indonesia, Jakarta: Yayasan Pendidikan Pasar Modal Indonesia \& Sinergy Communication.

Indonesia Brand Forum (2016). Insiprasi Branding Perusahaan Keluarga dari Indonesian Brand Forum 2016. Diakses dari

https://tangandiatas.com/2016/09/08/in spirasi-branding-perusahaan-keluargadari-ibf-indonesian-brand-forum-2016/

Islam, S, 2014, "Peran dan Tanggung jawab Komisaris Perseroan dalam Mengimplementasi Good Corporate Governance (GCG)", Tesis, Magister Ilmu Hukum Universitas Gadjah Mada Yogyakarta

Jensen, M.C. \& Meckling, W.H. (1976) Theory of The Firm: Managerial Behaviour, Agency Cost and Ownership Structure. Journal of Financial Economics Volume 3 No 4, hlm 305-360. 
KNKG (2006). Pedomana Umum Good Corporate Governance Indonesia.

KNKG. (2010). Pedomana Good Corporate Governance Indonesia Perusahaan Asuransi dan Perusahaan Reasuransi Indonesia. Diunduh dari http://www.knkg-indonesia.org/

LeMar, B. 2001, Generations-und Fiihrungswechsel in Familienunternehmen. Springer-Verlag Berlin Heidelberg.

Lukviarman, N. 2016 Corporate Governance. Penerbit: PT Era Adicitra Intermedia.

Oman, C. 2001, Corporate Governance and National Development, Technical Paper No. 180, OECD Development Centre.

Saputra, I.A., 2010, "Peranan Komisaris Independen dalam Mewujudkan Good Corporate Governance (GCG) pada Bank Nagari", Tesis, Magister Ilmu Hukum Universitas Gadjah Mada Yogyakarta

Schwass, J.,.Amann, W. \& Ward, J. 2004, Die nachste Generation. Zeitschrift Fiihrung + Organisation Volume 73 No 5, hlm 260-265.

Solomon, J., \& Solomon, A. 2004, Corporate Governance and Accountability. England: John Wiley and Sons, Ltd.

Susanto, A.B. 2007, The Jakarta consulting group on family business. Jakarta : The Jakarta Consulting Group.

Utami, C.D., 2007, "Fungsi dan Peranan Komisaris Independen dalam Perusahaan Go Public di Indonesia", Tesis, Magister Ilmu Hukum Universitas Gadjah Mada Yogyakarta

Vazquez, P., Carrera, A. \& Cornejo, M. 2019, Corporate Governance in the largest family firms in Latin America, Cross Cultural \& Strategic Management

Wijaya, A. \& Wijaya, B. (2017). Analisis Suksesi pada Bisnis Keluarga Berbasis Family Owned Enterprise (FOE). Conference on Management and Behavioral Studies, hlm. 186-193.

Wolk, et al (2001). Signaling, Agency Theory, Accounting Policy Choice. Accounting and Business Research. Vol. 18. No 69:47-56.

Yeh,Y.H. 2017, Corporate Governance and Family Succession: New Evidence from
Taiwan. Pacific-Basin Finance Journal. Elsevier. 